\title{
Corporate governance and international bond issues by Latin American corporations
}

\author{
Georgina Núñez Reyes, Ignacio Perrotini Hernández \\ and Francisco López-Herrera
}

\begin{abstract}
This paper analyses the relationship between corporate bond issues and the existence of corporate governance frameworks that influence the development of financial markets by reducing information asymmetries and conflicts of interest. To this end, the international corporate bond market is reviewed and corporate governance standards in Brazil and in the four countries belonging to the Latin American Integrated Market (MILA) - Chile, Colombia, Mexico and Peru - are evaluated using a bond issues indicator developed by the Economic Commission for Latin America and the Caribbean (ECLAC), the Andean Development Corporation (CAF) and the Inter-American Development Bank (IDB). The evidence gathered using a probit panel model and a pooled probit model indicates that adherence to corporate governance standards can increase the likelihood that a firm will be able to carry out a successful international bond issue.
\end{abstract}

\section{Keywords}

Business financing, corporate governance, rules and regulations, capital markets, bond, corporate debt, econometric models, Latin America and the Caribbean

JEL classification

F65, G15, G32

\section{Authors}

Georgina Núñez Reyes is an Economic Affairs Officer with the Production, Productivity and Management Division of the Economic Commission for Latin America and the Caribbean (ECLAC). Email: georgina.nunez@un.org.

Ignacio Perrotini Hernández is the Coordinator for the Postgraduate Programme in Economics of the Autonomous National University of Mexico (UNAM). Email: iph@unam.mx.

Francisco López-Herrera is a Research Professor with the Faculty of Accounting and Administration of the Autonomous National University of Mexico (UNAM). Email: francisco_lopez_herrera@yahoo.com.mx. 


\section{Introduction}

Gozzi and others (2015) note that, for the period 1991-2013, corporate bond issues accounted for nearly $80 \%$ of all the capital raised by business enterprises worldwide and over $90 \%$ of the capital that they raised in markets outside their home countries. This shows just how important these markets are becoming under financial globalization. Since 2009, the corporate bond market has come to exert a growing influence over firms' financing decisions in Latin America. In fact, as shown in figure 1, the total stock of international corporate debt is four times higher than its pre-crisis level. Since debt instruments represent future payment obligations on the part of different economic agents, what happens in this market will necessarily have an impact in terms of the stability of the global economy.

Figure 1

Total international corporate debt as at the end of each quarter, 2000-2015

(Billions of dollars)

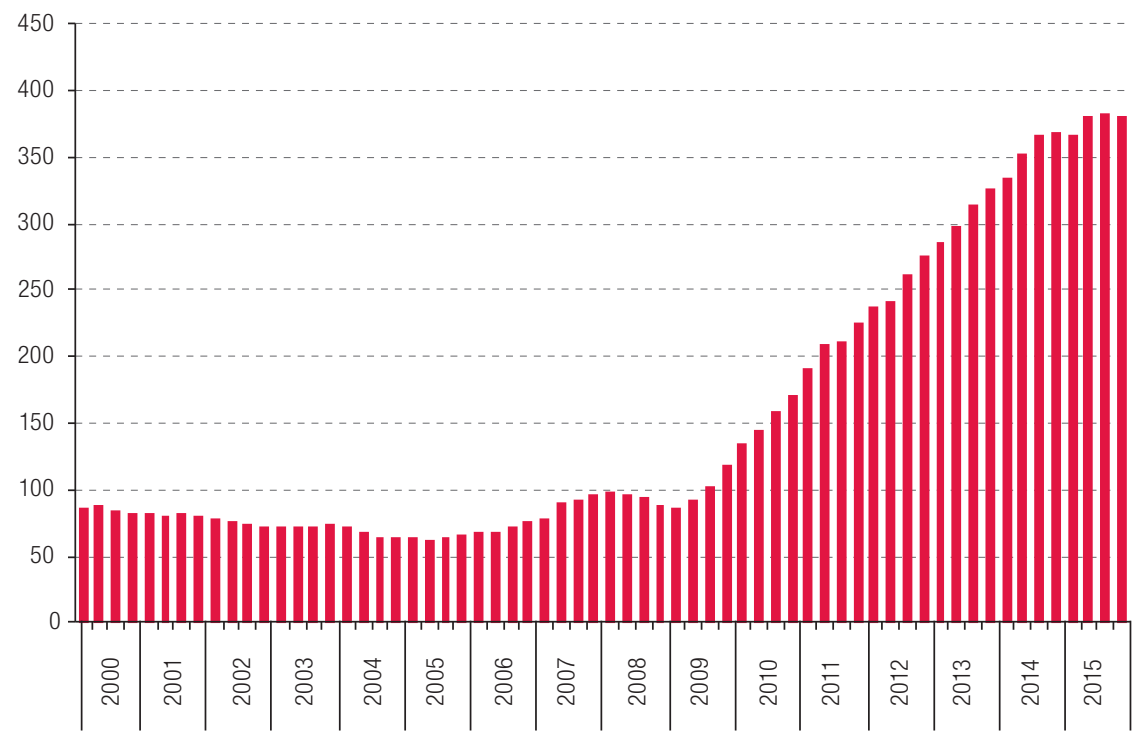

Source: Prepared by the authors, on the basis of Bank for International Settlements (BIS), "Debt securities statistics", 2016 [online] https://www.bis.org/statistics/secstats.htm?m=6\%7C33\%7C615.

International bond issues tend to have a greater impact on developing economies than domestic issues do. Çelik, Demirtas and Isaksson (2015) and Rodrigues, Kamil and Sutton (2015) attribute the growth of corporate debt in Latin America to international market conditions, which have been reflected in an appreciation of the currencies of Latin American countries against the dollar and in near-zero interest rates in the United States. In late 2014, the financial landscape changed when the United States Federal Reserve stopped applying its policy of quantitative easing, ${ }^{1}$ under which had been buying up securities as a way of injecting liquidity into capital markets. Over the six years that this policy was in place, about US\$ 4.5 billion in liquidity was transferred to developing economies, where it was used to finance corporate investments.

When this policy was discontinued, Japanese and European central banks tried to maintain the existing level of liquidity in financial markets by launching equivalent policy packages involving US\$ 2.5 billion; these measures entailed the introduction of expansionary monetary policies by the

\footnotetext{
1 The objective of quantitative easing was to lower long-term interest rates in order to spur aggregate demand and economic growth.
} 
main developed economies (Núñez and Oneto, 2014). ${ }^{2}$ According to Pérez Caldentey (2017), since the introduction of quantitative easing policies, the share of international bond markets in total lending to non-residents has risen from $40 \%$ to $48 \%$.

The most dynamic actors in this area have been residents of Asia and Latin America. Between 2009 and 2015 , international debt issues jumped by $12 \%$ in these regions, whereas, in developed countries, they edged up by a mere $0.23 \%$ during that period.

The expansion of debt stocks, coupled with the corporate scandals that came to light during the 2008 crisis, prompted bond purchasers, especially in the developed world, to bring stronger pressure to bear on regulators to improve the corporate governance of firms that issue bonds. ${ }^{3}$ Particularly in the case of the financial system, corporate governance has come to be viewed as a powerful risk-mitigation tool. Improvements in this area that are seen as a way of protecting investors from fraudulent practices include increases in the flow of information and a reduction of information asymmetries between the parties to transactions involving debt issues, such as mergers and acquisitions.

The increase in corporate leveraging that has resulted, in part, from the upswing in the issuance of debt instruments observed since 2010 has been used to restructure existing debt (Gozzi and others, 2015). This has alerted the market and regulatory authorities to the possibility of defaults that could have system-wide impacts, not only on national and regional economies but on the global economy as well, especially since the corporate default rate has hit its highest point since 2009, according to Standard \& Poor's (Financial Times, 2016). In the course of integration processes such as the formation of the Latin American Integrated Market (MILA), ${ }^{4}$ the various countries' regulations and standards have to be aligned as much as possible so that the integration process will produce the fewest possible distortions in the national markets exhibiting good corporate governance practices. The various types of factors that limit corporate governance structures' ability to meet development challenges and those posed by the integration of financial markets, which include market failures (e.g. information asymmetries), along with the factors that hamper the effectiveness of regulatory schemes and their application, call for a more in-depth analysis.

Effective corporate governance schemes set within a broad legal framework and corporate strategy contribute to capital market development, reduce market failures and facilitate access to different sources of financing. The objective of this analysis is to provide evidence to show how effective corporate governance can increase the likelihood of successful bond issues.

2 Rogoff (2015) states that, with its quantitative easing policy, the Federal Reserve signalled the economy that, if long-term interest rates were to rise sharply, it would be willing to sustain the heavy losses it would incur by holding a large amount of old low-interest bonds. If the central bank buys only government debt, then its losses have little economic meaning. The fact that central banks filled their portfolios with low-yielding long-term debt helped to convince investors that they would keep short-term interest rates low for as long as possible. Rogoff concludes that quantitative easing is a weaker and more uncertain instrument than normal interest-rate policy.

3 In an article published in América Economía, Tromben and others (2015) discuss the corporate governance failures revealed by a series of scandals in Latin American firms. They attribute these failings to shortcomings in the control exercised by decision-making bodies over dealings that weakened pension funds and allowed pension fund administrators to divert funds to political campaigns and parties, thereby also violating election laws. The firm SQM in Chile was one such case. Other cases, such as that of Petrobras, have been even more dramatic, since they have undermined the financial health of State-owned companies. In Chile, a proposal has been put forward for modifying the regulatory framework with a view to achieving a greater disaggregation of information on conflicts of interest, risk management, in-house whistle-blowing, compensation and the involvement of shareholders meetings.

4 The Latin American Integrated Market (MILA) was originally formed by the stock exchanges of Chile, Colombia and Peru, had 563 listed companies and began operations in November 2010. Its initial total market capitalization of US\$660.985 billion -Chile had a 50.6\% share (US\$334.461 billion), Colombia, 33.55\% (US\$221.775 billion) and Peru, 15.85\% (US\$104.749 billion) - made MILA the second-biggest exchange market in the region, after Brazil, which had a market capitalization of US\$1,747,315,000,000. In terms of trading volumes, MILA was the third-largest market in Latin America, with US\$ 57 billion in trades per year, after Brazil (US\$ 633 billion) and Mexico (US\$ 87 billion). Mexico, with an exchange market capitalization of US\$ 457.997 billion, joined MILA in 2014. The largest share of securities in Peru came from mining companies (53\%), while in Colombia the main source was industry (78\%); in the case of Chile, the services sector accounted for $32 \%$ of its market capitalization. For further information, see [online]: mercadomila.com. 
The first of the following sections provides background information, with special emphasis on Brazil and the four member countries of MILA, concerning the Latin American debt market and international bond issues, which have become the preferred avenue for corporate borrowing since the financial crisis of 2008. The discussion will then turn to the concept of corporate governance based on the regulatory frameworks and best practice codes in place in each of the selected countries. This will be followed by an econometric analysis of the influence exerted by a series of variables, including corporate governance, on securities issues. Conclusions are presented in the last section.

\section{The Latin American securities market}

Debt markets - and particularly corporate bond markets - were extremely buoyant during the period from 1 January 2005 to 31 December 2015. The 14,630 international and domestic corporate bond issues of 23 Latin American and Caribbean countries ${ }^{5}$ in 2005-2015 totalled US\$ 1.36 trillion and, of that total, nearly 60\% (US\$ 805 billion) was accounted for by international issues. Brazil, with an almost $40 \%$ share, and Mexico, with 29\%, were the biggest issuers of international corporate debt (see table 1). In terms of the number of issues, Brazil accounted for nearly $75 \%$ of the total, followed by Chile, with close to $10 \%$.

Table 1

Latin America and the Caribbean: international corporate bond issues, 2005-2015

\begin{tabular}{lcccc}
\hline & $\begin{array}{c}\text { Value } \\
\text { (billions of dollars) }\end{array}$ & $\begin{array}{c}\text { Value } \\
\text { (percentages) }\end{array}$ & $\begin{array}{c}\text { Number } \\
\text { (units) }\end{array}$ & $\begin{array}{c}\text { Number } \\
\text { (percentages) }\end{array}$ \\
\hline Total issues & 805.25 & & 6728 & 74.8 \\
\hline Brazil & 320.89 & 39.9 & 5032 & 6.0 \\
\hline Mexico & 236.88 & 29.4 & 403 & 9.9 \\
\hline Chile & 72.88 & 9.1 & 666 & 0.5 \\
\hline Venezuela (Bol. Rep. of) & 50.64 & 6.3 & 34 & 1.1 \\
\hline Colombia & 34.81 & 4.3 & 73 & 1.5 \\
\hline Peru & 32.71 & 4.1 & 102 & 1.9 \\
\hline Argentina & 15.71 & 2.0 & 288 & 4.3 \\
\hline Other & 40.73 & 5.1 & & \\
\hline
\end{tabular}

Source: Prepared by the authors on the basis of information from Bloomberg.

The international issues included in the sample were originally denominated in 22 different currencies. As shown in figure 2, however, 88\% of them were conducted in United States dollars, with euro-denominated issues coming in a distant second (7\%). This distribution may have become even more unbalanced in recent years, given the strengthening of the dollar since late 2014.

Figure 3 depicts the distribution of total debt issues by economic sector. According to figures published by Bloomberg, the largest issues in terms of value are mainly found in the energy sector, which accounts for $29 \%$ of total issues by value but just 3.2\% by number of bond issues in the region. The financial sector accounts for $28 \%$ of the total by value and for nearly $83 \%$ by number of international issues of debt securities.

\footnotetext{
5 Argentina, Bahamas, Barbados, Belize, Bolivarian Republic of Venezuela, Brazil, Chile, Colombia, Costa Rica, Dominican Republic, Ecuador, El Salvador, Guatemala, Mexico, Nicaragua, Panama, Paraguay, Peru, Plurinational State of Bolivia, Saint Vincent and the Grenadines, Trinidad and Tobago, and Uruguay.
} 
Figure 2

Latin America and the Caribbean: currencies used in international debt issues, 2005-2015 (Percentages)

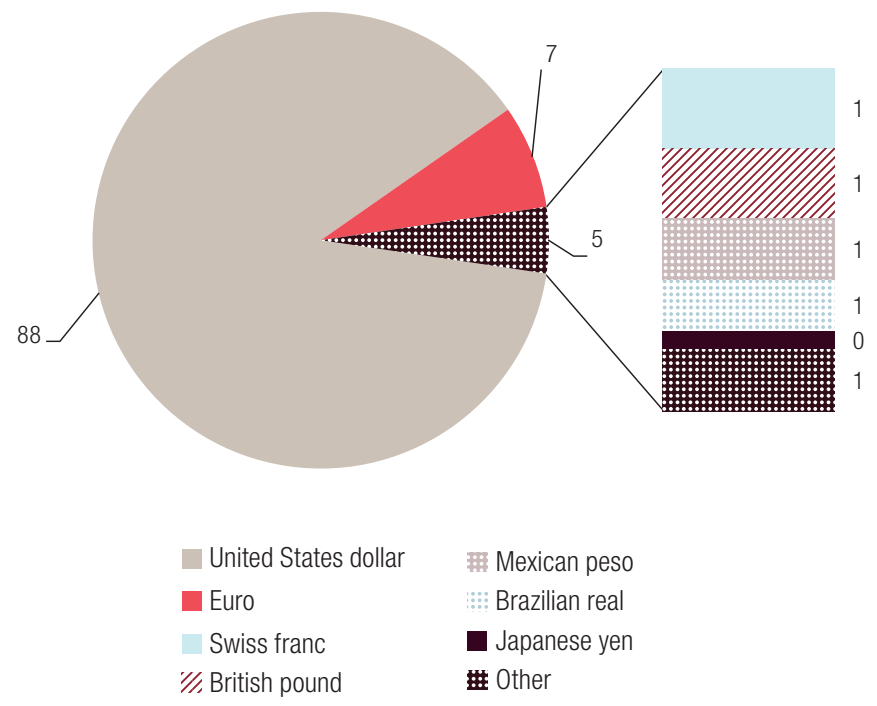

Source: Prepared by the authors on the basis of information from Bloomberg.

Figure 3

Latin America and the Caribbean: distribution of international bond issues, by value and sector of activity, 2005-2015

(Percentages)

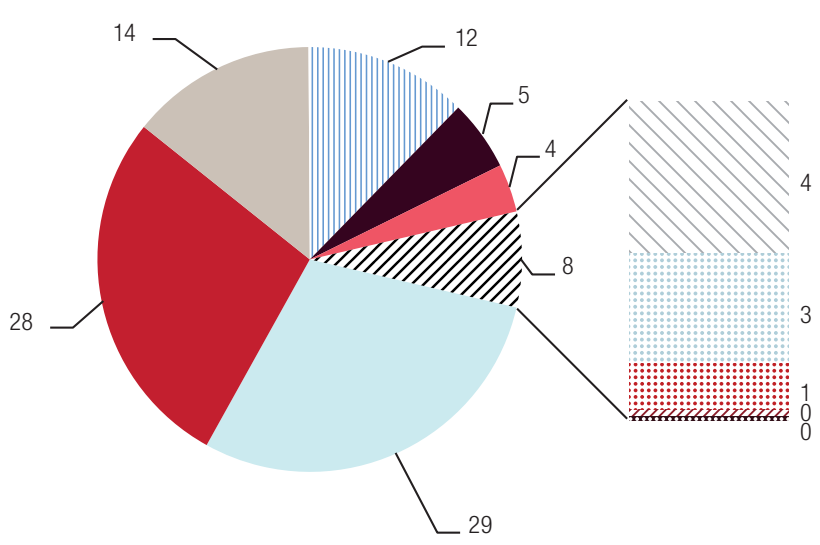

$\begin{array}{lll}\text { Energy } & \text { : Government } & \text { Industrials } \\ \text { Materials } & \text { Technology } & \text { Consumer products - discretionary } \\ \text { C Consumer staples } & \text { Financials } & \text { \%. Health care } \\ \text { ' Public services } & |||| \text { Communications } & \end{array}$

Source: Prepared by the authors on the basis of information from Bloomberg.

Just seven countries of the region accounted for a full 95\% of bond issues: the four MILA countries, Argentina, Brazil and the Bolivarian Republic of Venezuela. The other 16 countries were the source of the remaining $5 \%$ of the region's international corporate issues. The largest percentage of bond issues came from the non-financial sector (see figure 4). 
Figure 4

Latin America and the Caribbean (22 countries): bond issues of the financial and non-financial sectors, 2005-2015

(Percentages)

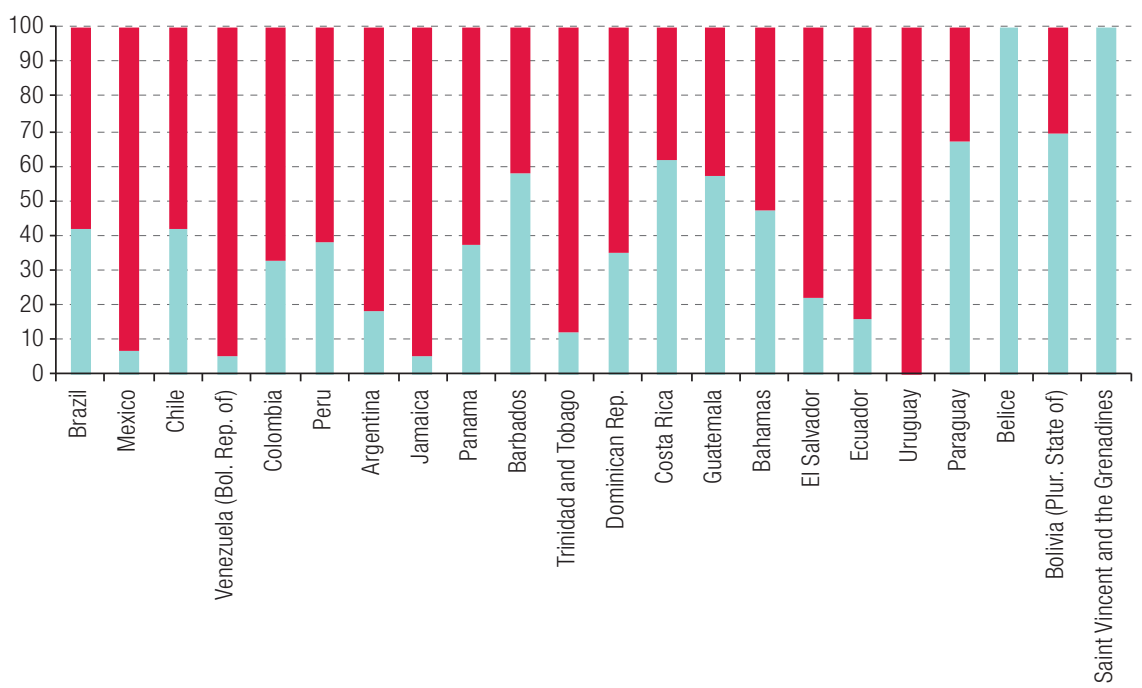

Financial sector $\quad$ Non-financial sector

Source: Prepared by the authors on the basis of information from Bloomberg.

Figure 5 shows the distribution of the countries where corporate debt was placed: $26 \%$ of total bond issues were placed in the Mexican market and 19\% in Brazil. Although 10\% of the total debt was placed by a firm in the Netherlands, the corresponding risk is located in one or another country of the Latin American and Caribbean region. The Cayman Islands, which are generally regarded as a tax haven, account for $9 \%$ of total debt placements.

Figure 5

Recipient countries of Latin American and Caribbean debt placements, 2005-2015 (Percentages)

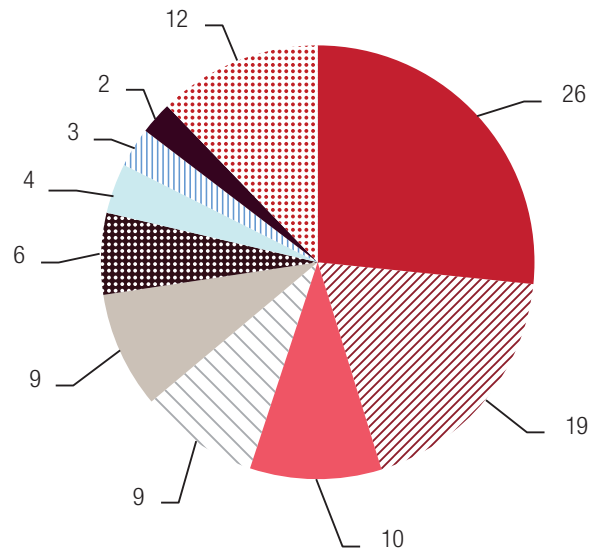

\begin{tabular}{|c|c|c|}
\hline Mexico & "y. Brazil & Netherlands \\
\hline$\backslash$ Cayman Islands & Chile & 眊 Venezuela (Bol. Rep. of) \\
\hline $\begin{array}{l}\text { United States } \\
:: \text { Other }\end{array}$ & |||| Colombia & Deru \\
\hline
\end{tabular}

Source: Prepared by the authors, on the basis of information from Bloomberg. 


\section{Corporate governance, regulatory frameworks and best practice codes}

The absence of efficient, comprehensive autonomous mechanisms for monitoring corporate risk is one of the main problems that has come to light in recent years. The lack of the necessary specialized units within corporate governance structures is especially apparent at the corporate decision-making level. ${ }^{6}$

The risk classification criteria used by the MILA countries are similar to those used by credit rating agencies to assess issuers' ability to meet their payment obligations to investors within the time frames and on the terms stipulated in their contracts. An analysis of the figures raises some doubts, however, about how the application and effectiveness of some of their risk assessment methods are monitored and about the ways in which firms arrive at their decisions regarding leveraging. ${ }^{7}$ The corporate governance regulatory frameworks examined in this section are the ones that were in place in 2005-2015. Issuers' decisions are in line with an effective corporate governance structure as perceived and appraised by the various market agents (institutional investors, credit rating agencies and issuing banks). The corporate governance index examined here is used to determine whether these aspects of corporate governance (subject to the existing regulations and best practice codes) are in line with increased access to the bond market under better terms and conditions.

The indicator used to assess corporate governance regulations and standards as they relate to issues of debt instruments was developed by the Economic Commission for Latin America and the Caribbean (ECLAC), the Development Bank of Latin America (CAF) and the Inter-American Development Bank (IDB) (Núñez and Oneto, 2012). It is based on international standards, including the corporate government principles framed by the Organization for Economic Cooperation and Development (OECD, 2016), and encompasses 9 categories and 19 different standards (see table 2). ${ }^{8}$

\footnotetext{
6 Núñez and Oneto (2015) apply an indicator that has been constructed for use in measuring the quality of corporate governance in firms in five countries of the region. Their findings indicate that most of these firms did not have a committee whose main job was to monitor risk levels on an ongoing, comprehensive basis. For the most part, risk assessment committees and audit committees are the areas in which the greatest improvements in corporate governance are required in the region and particularly in the MILA countries and Brazil.

7 In conducting risk assessments, emphasis is placed on information concerning bond spreads, and risk is interpreted as the spread between the yield of the bond in question and the yield of a zero-coupon bond for the same term of the United States Treasury Department. For the sample of firms used for this analysis for the period from 2005 to 2015, that spread averaged around $4.30 \%$.

8 This indicator was constructed on the basis of a number of international corporate governance standards, including the corporate governance principles of OECD (OECD, 2016) and CAF (2013), and national standards such as The UK Corporate Governance Code (FRC, 2011) and The Combined Code of Corporate Governance (FRC, 2008). It is designed to serve as a qualitative measuring tool for gauging the level of risk and of internal control specifically relating to a firm's bond issues. This is done in three stages: (i) the identification, in the aggregate, of the main procedures involved in issuing corporate bonds for which the board of directors is directly responsible, which include determining the firm's financing requirements, selecting and approving the engagement of the financial intermediaries who will be in charge of the bond issue, determining the level of risk associated with the issue and monitoring it, authorizing the issue based on the information it receives regarding the use made of the funds raised by that means and the implications of the firm's leveraging, and designing the internal control systems used to gather timely information on the effectiveness of risk management operations and the performance of the firm's directors; (ii) the definition of corporate governance standards having an impact on bond issues; and (iii) the definition of the criteria used to determine the relative importance of specific standards. For more detailed information on this indicator, see Núñez and Oneto (2012).
} 
Table 2

Indicator for corporate governance/international bond issues

\begin{tabular}{|c|c|c|c|c|}
\hline Category & & Standard & $\begin{array}{l}\text { Weighting } \\
\text { (percentages) }\end{array}$ & $\begin{array}{l}\text { No. of } \\
\text { questions }\end{array}$ \\
\hline \multirow[t]{2}{*}{$\begin{array}{l}\text { Role of the board } \\
\text { of directors }\end{array}$} & 1 & $\begin{array}{l}\text { The board of directors sets up mechanisms for obtaining reliable information } \\
\text { on all of the company's investments in financial and non-financial assets } \\
\text { and its financing activities. }\end{array}$ & 15.52 & 1 \\
\hline & 2 & $\begin{array}{l}\text { The board of directors delegates responsibilities and functions only to corporate } \\
\text { committees that are chaired by an independent external officer. }\end{array}$ & 5.84 & 1 \\
\hline $\begin{array}{l}\text { Structure of the board } \\
\text { of directors }\end{array}$ & 3 & The board of directors is of a size that will permit it to arrive at decisions expeditiously. & 0.94 & 2 \\
\hline \multirow[t]{2}{*}{$\begin{array}{l}\text { Role of the chairperson } \\
\text { of the board }\end{array}$} & 4 & $\begin{array}{l}\text { The chairperson sets up mechanisms for selecting non-executive directors } \\
\text { on the basis of the value they can bring to the table. }\end{array}$ & 3.98 & 1 \\
\hline & 5 & The chairperson is an independent external officer. & 1.88 & 1 \\
\hline $\begin{array}{l}\text { Role and selection } \\
\text { of executive or inside } \\
\text { directors and of } \\
\text { non-executive or } \\
\text { outside directors }\end{array}$ & 6 & Directors keep abreast of the needs of the company and its employees. & 7.79 & 2 \\
\hline $\begin{array}{l}\text { External or } \\
\text { independent directors }\end{array}$ & 7 & $\begin{array}{l}\text { Non-executive directors advise the board of any conflict of interest relating } \\
\text { to the company. }\end{array}$ & 5.84 & 1 \\
\hline \multirow[t]{2}{*}{ In-house directors } & 8 & $\begin{array}{l}\text { Executive directors sign documents whereby they assume legal responsibility } \\
\text { for the information that they provide and disseminate and whereby they would } \\
\text { be criminally liable for any violation in that regard and for any failure to divulge } \\
\text { information to the board. }\end{array}$ & 7.77 & 2 \\
\hline & 9 & $\begin{array}{l}\text { The executive auditor is a member of the board of directors and reports directly } \\
\text { to the board or to one of its committees. }\end{array}$ & & \\
\hline \multirow[t]{4}{*}{ Audit committee } & 10 & $\begin{array}{l}\text { The audit committee is chaired by an independent external officer having expertise } \\
\text { in internal control. The external auditor is engaged by the audit committee and reports } \\
\text { directly to that committee. }\end{array}$ & 19.40 & 2 \\
\hline & 11 & $\begin{array}{l}\text { The audit committee approves the auditing programmes and follows up } \\
\text { on the observations made by the auditors. }\end{array}$ & & \\
\hline & 12 & The audit committee approves the design and operation of the internal control system. & & \\
\hline & 13 & $\begin{array}{l}\text { The audit committee is responsible for ensuring that an effective reporting system } \\
\text { is in place that covers, in particular, financial aspects, risk management and the } \\
\text { performance of the company and of the board. }\end{array}$ & & \\
\hline \multirow[t]{2}{*}{$\begin{array}{l}\text { Corporate } \\
\text { finance committee }\end{array}$} & 14 & $\begin{array}{l}\text { The corporate finance committee is chaired by an independent external officer with } \\
\text { expertise in that field. } \\
\text { The corporate finance committee determines the firm's financing requirements } \\
\text { and must approve the use of the financing mechanisms proposed by the firm's } \\
\text { general managers. }\end{array}$ & 15.52 & 4 \\
\hline & 15 & $\begin{array}{l}\text { The corporate finance committee must approve the selection and recruitment } \\
\text { of the financial intermediaries required to place the securities issued by the firm. }\end{array}$ & & \\
\hline \multirow[t]{4}{*}{$\begin{array}{l}\text { Risk management } \\
\text { committee }\end{array}$} & 16 & $\begin{array}{l}\text { The risk management committee is chaired by an independent external officer } \\
\text { with expertise in comprehensive risk management. }\end{array}$ & 15.52 & 3 \\
\hline & 17 & $\begin{array}{l}\text { The risk management committee must approve the financial and credit risk reports } \\
\text { prepared by the firm's risk management unit. }\end{array}$ & & \\
\hline & 18 & $\begin{array}{l}\text { The risk management committee reports regularly to the firm's general management } \\
\text { and to the board of directors on the effectiveness of the investment strategy. }\end{array}$ & & \\
\hline & 19 & $\begin{array}{l}\text { The risk management committee must approve the plan for the management } \\
\text { (via mitigation, containment or transfer) of the non-financial risk detailed in the reports } \\
\text { of the firm's general management. }\end{array}$ & & \\
\hline Total & & & 100 & \\
\hline
\end{tabular}

Source:Prepared by the authors on the basis of G. Núñez and A. Oneto (coords.), "Gobernanza corporativa en el Brasil, Colombia y México: la determinación del riesgo en la emisión de instrumentos de deuda corporativa", Project Documents (LC/W.468), Santiago, Economic Commission for Latin America and the Caribbean (ECLAC), 2012.

The first three components (the role of the board of directors, its structure and the role of the board's chairperson) establish the overall framework for the firm's corporate governance system. The next three components correspond to the three specialized committees that provide information to the board on specific aspects of the bond issue. The indicator is based on questions that elicit a yes or no response: if the answer is "yes", it takes a value of 1 ; if the answer is "no", it takes a value of 0 . 
It is then normalized to produce a range of values from 0 to 10 . This indicator was developed as a tool for the direct assessment of the corporate governance performance of 22 firms in Brazil and the four MILA countries that issue bonds, but it could also be used to evaluate the laws and best practice codes governing this activity. For the purposes of this study, both the standards and the original questions, as well as their weightings, have been adjusted. Almost all of the same categories were used, with the exception of those relating to financial investment committees, and the questions relating to each standard were modified to focus solely on the relevant laws, regulations and best practice codes; in addition, the mandatory standards (laws and regulations) and voluntary standards (best governance practice codes) were merged. The category weightings remained the same, and the weightings for the committee that was omitted were distributed among the others. In the standards matrix (see table 2) for evaluating the regulatory framework for corporate governance, transparency is a factor that cuts across all the categories included in the indicator. It figures in most of the individual standards and is the reason why the indicator can be applied to any type of international or national bond issue rather than only to government issues or the issues of listed companies.

These standards apply to capital markets and, in most cases, these corporate governance best practice codes are part of the package of information that stock exchanges request on a regular basis. This indicator is used to evaluate the standards applied by each of the selected countries and produces a single value for each country and each year. The requirement to report on corporate governance is, in many cases, discretionary and is based on the principle of "comply or explain". And this, in combination with the fact that relatively few firms are subject to corporate governance standards, may cancel out their possible effect in reducing information asymmetries.

One of the ways in which corporate governance standards have been changing is that more and more importance is being placed on having a larger number of non-executive (i.e. independent) directors on corporate boards. Improvements in this respect have been observed in many cases. This is especially important in cases of ownership concentration, where one agent owns over $50 \%$ of the equity in a firm. When the indicator was used to assess the prevailing standards and codes, the values shown in table 3 were obtained. The aggregate measurements of the corporate governance standards applying in the four MILA countries and in Brazil indicate that the performance of these five countries' regulatory agencies is quite similar and reflect the effort that has been made in recent years to improve and align their regulatory frameworks.

Table 3

Latin America (5 countries): corporate governance indicators, 2005-2015

\begin{tabular}{|c|c|c|c|c|c|c|c|c|c|c|c|}
\hline Country & 2005 & 2006 & 2007 & 2008 & 2009 & 2010 & 2011 & 2012 & 2013 & 2014 & 2015 \\
\hline Brazil & 4.27 & 4.27 & 5.06 & 5.06 & 5.06 & 5.06 & 5.06 & 6.14 & 6.14 & 6.14 & 6.14 \\
\hline Chile & 2.56 & 2.56 & 2.56 & 2.56 & 2.56 & 3.06 & 3.06 & 3.58 & 6.84 & 6.84 & 7.25 \\
\hline Colombia & 0.93 & 2.99 & 2.99 & 5.12 & 5.12 & 5.12 & 5.12 & 5.12 & 5.12 & 5.12 & 7.66 \\
\hline Mexico & 4.48 & 6.19 & 6.19 & 6.19 & 6.19 & 6.19 & 6.45 & 6.45 & 6.45 & 6.71 & 7.12 \\
\hline Peru & 4.39 & 4.39 & 4.39 & 4.39 & 4.39 & 4.39 & 4.39 & 4.39 & 4.39 & 7.76 & 7.76 \\
\hline
\end{tabular}

Source: Prepared by the authors on the basis of official information from the countries.

The country with the lowest rating in 2015 was Brazil. This result is accounted for by the way in which risk is analysed and managed and by the existence of a provision under which one third of the members of boards of directors can be executives of the company in question (opening the way for potential conflicts of interest). Under Brazilian law, there must be a board of directors, but there must also be a fiscal council. The highest rating for 2015 is for Peru, and Colombia was the country that saw the greatest improvement in this respect for the period as a whole. Chile is the only one of the five countries that does not have a best practices code. 
As far as the indicator's coverage of the different categories is concerned, Chile has the best standards concerning the role of boards of directors (standard No. 1) thanks to the amendments made to Corporations Act No. 18.046 of 2009. In the case of the structure of the boards (standard No. 2), the regulations of Colombia and Mexico both require at least $25 \%$ of board members to be independent. ${ }^{9}$ None of the countries' provisions regarding the role of the chairperson of the board of directors (standard No. 3) stands out from the rest, although those of Chile, Colombia and Peru do explicitly state that, whether directly or indirectly, the general manager cannot chair the board of directors. The ratings differ in the cases of the audit committees (standard No. 4) and risk management committees (standard No. 5). Between 2004 and 2015, all the countries' legislatures except Peru's took steps to require firms to have audit committees, but this has not been done in the case of dedicated risk management or corporate finance committees.

Generally, speaking, the biggest improvements in the legal framework for corporate governance in the four MILA countries and Brazil occurred between 2013 and 2014. In the MILA countries, this probably has to do with the fact that they had to harmonize their laws in order to integrate their stock exchanges. In addition, some of the changes came on the back of corporate scandals in some countries (for example, the La Polar scandal in Chile) and of sectoral reforms in others (as in Mexico). The lowest ratings are for information on corporate committees and their responsibilities, especially in the areas of risk management and auditing. Information on how bond issues are financed is seen to be important, but few companies have specialized corporate committees to deal with that subject. There are no laws or regulations that deal specifically with State-owned companies that issue securities, but Núñez and Oneto (2015) found that the corporate governance structures of State-owned firms included some type of specialized unit dealing with financing and investments in financial assets, which did not tend to be the case in most of the private firms in their sample. ${ }^{10}$

\section{Econometric analysis}

The data used for this analysis correspond to the international bond issues registered in the Bloomberg database for 2005-2015. During this period, 323 firms out of the 2,130 listed companies in the four MILA countries and Brazil conducted a total of 5,173 international bond issues. This sample was drawn from the group of firms for which balance sheets were available for at least one of the years in the study period. The "residence of issuer" approach was used to classify corporate bond markets. ${ }^{11}$ Issues classified as domestic ("domestic" and "domestic medium-term notes") and private placements were removed in order to ensure that only international issues from parent companies or their subsidiaries were included. The average term of the bonds was 10 years and the median term was 8 years. These issues were denominated in 15 different currencies, but $80 \%$ of them were in United States dollars.

The decision to undertake a bond issue can be represented by a binary dummy variable, $B o n d_{i t}$, that can take either one of two values: yes $=1$ with a probability of $p_{i}$, no $=0$ with a probability of $\left(1-p_{i}\right)$.

9 Bhagat and Bolton (2008) find that the degree of independence of a board of directors is negatively correlated with a firm's operational performance. This is of particular significance, given the special importance that regulations applying to listed companies place on their having independent boards.

10 The sample used by Núñez and Oneto (2015) included State-owned companies, which tended to perform better than private firms in other sectors of the economy (the financial, services and manufacturing sectors) in terms of corporate governance. Companies in Chile and Peru had better ratings than firms in the other countries, primarily because they had at least three of the corporate committees identified in the indicator, while the other firms in the sample did not. A greater rigidity in the rules governing domestic equity and local bond markets was observed that tended to spill over into international debt markets.

${ }^{11}$ According to the residence of issuer approach (BIS/ECB/IMF, 2015, para. 7.61), "debt securities issued by a resident of the same economy in which the security is issued are classified as domestically issued, regardless of the currency of issue. All other issues are classified as internationally issued." 
In other words:

$$
\operatorname{Prob}\left(\text { Bond }_{i t}=1 \mid x, \beta\right)=p_{i}=F(x, \beta)
$$

Given the characteristics of the database, a probit model for panel data was chosen in which $F(x, \beta)$ is the cumulative distribution function of the normal standard distribution $\int_{-\infty}^{x \beta} \frac{1}{\sqrt{2 \pi}} e^{-\frac{z^{2}}{2}} d z$. The estimated model is:

$$
\text { Bond }_{i t}=x_{i t}^{\prime} \beta+\varepsilon_{i t}
$$

The parameters can be estimated by finding the ones that maximize the logarithm of the joint likelihood function:

$$
\ln L(\beta)=\sum_{i=1}^{n} \sum_{t=1}^{T}\left\{\left(\text { Bond }_{i t}\right) \ln F\left(x_{i}, \beta\right)+\left(1-\text { Bond }_{i t}\right) \ln \left(1-F\left(x_{i}, \beta\right)\right)\right\}
$$

In this analysis, use is made of three of the five accounting ratios discussed by Mizen and Tsoukas (2012) for assessing companies' financial health on the basis of their financial statements. The first is a one-period lagged leverage ratio, $\operatorname{Lev} R_{i t-1}$ (total debt/total assets). If the value of this ratio is high, investors will either think that the company will not be able to meet its payment obligations and will not want to buy its bonds (negative response) or will think that it is creditworthy and that there will therefore be a greater likelihood that its bonds will be in demand (positive response). The square of the previous variable, $L e v R_{i t-1}^{2}$, is used in order to check whether or not there is a maximum (optimum) level of debt relative to assets after which there would be a change of direction in the response curve for the relationship between the dependent variable and the firm's leverage (see Margaritis and Psillaki, 2010). In order to capture the profitability effect, the $\operatorname{Prof} R_{i t-1}$ variable (defined as earnings before interest and taxes (EBIT)/total assets) is included; lower EBITs point to the probability that a firm will seek external financing.

The model used here included other variables, in addition to the above. One of these is Size_it, which denotes the size of the firm. It is assumed that the bigger the firm, the more likely it is to issue bonds. Another variable is $C E M B I$, which is an index for dollar-denominated corporate bonds issued by emerging markets. Another is the $\operatorname{CorpGov}_{j t}$ corporate governance index, which measures a firm's performance in terms of regulatory compliance and is assumed to correlate positively with the likelihood that a firm will seek financing on the bond market. This assumption is based on the expectation that the solid reputation which an issuer earns by complying with the corresponding laws and regulations will increase the probability that its bond issue will be successful. The model also includes the Deriv and $\operatorname{VarTC}$ variables, which measure the size of the derivatives market as reported by the Bank for International Settlements and variations in the exchange rate against the dollar in the country of the issuing firm, respectively. Dummy variables have also been included to take into account any influence that may be exerted by the year during which the issue is conducted and the scale of the sector of activity in which the company operates. Based on the foregoing, the specification of the model is as follows:

$$
\begin{aligned}
& P\left(\operatorname{Bond}_{i, j, t}=1\right)=F\left(\operatorname{CorpGov}_{i, j, t}+\operatorname{LevR}_{i, j, t-1}+\operatorname{LevR}_{i, j, t-1}^{2}+\operatorname{ProfR}_{i, j, t-1}+\operatorname{Size}_{i, j, t-1}+\right. \\
& \left.\operatorname{CEMBI}_{i, j, t-1}+\operatorname{Deriv}_{i, j, t-1}+\operatorname{VarTC}_{, t-1}+\sum D Y j_{, t}+\sum D S_{z}\right)
\end{aligned}
$$

where $i$ represents the individual issuer, $j$ stands for the issuer's country, $z$ is the sector in which the firm operates and $t$ is the time period. 
In order to estimate this equation, two methods are used: a random-effects probit model for panel data and a pooled probit model. A total of 6,457 observations were analysed. In order to correct for the potential problem of endogeneity due to simultaneity, all the explanatory variables are lagged. This reduces the probability that the independent variables will be correlated with the contemporaneous residual. Table 4 shows the results of the estimates.

Table 4

Member countries of the Latin American Integrated Market (MILA) and Brazil: estimated probit models, 2005-2015

\begin{tabular}{|c|c|c|c|c|}
\hline Variables & $\begin{array}{c}\text { (1) } \\
\text { Probit RE } 3\end{array}$ & $\begin{array}{c}\text { (2) } \\
\text { Marg. effects }\end{array}$ & $\begin{array}{c}\text { (3) } \\
\text { Pooled probit } 3 \\
\end{array}$ & $\begin{array}{c}(4) \\
\text { Marg. effects }\end{array}$ \\
\hline \multirow[t]{2}{*}{ Corporate governance index (L.CorpGov) } & $0.144^{* \star *}$ & $0.00252^{\star \star}$ & $0.120^{\star * *}$ & $0.00247^{\star *}$ \\
\hline & $(0.0509)$ & $(0.00102)$ & $(0.0342)$ & $(0.00105)$ \\
\hline \multirow[t]{2}{*}{ One-period lagged leverage ratio (L.LevR) } & $4.693^{\star \star \star}$ & $0.0819^{\star \star *}$ & $4.665^{\star \star \star}$ & $0.0960^{\star * *}$ \\
\hline & $(0.830)$ & $(0.0222)$ & $(0.719)$ & $(0.0153)$ \\
\hline \multirow[t]{2}{*}{ L.LevR squared (L.LevR²) } & $-4.575^{\star \star \star}$ & $-0.0799^{* * *}$ & $-4.576^{\star \star *}$ & $-0.0942^{\star * \star}$ \\
\hline & $(1.096)$ & $(0.0251)$ & $(0.971)$ & $(0.00787)$ \\
\hline \multirow[t]{2}{*}{ Earnings before interest and taxes/total assets (L.ProfR) } & $-1.32 \mathrm{e}-08$ & $-2.31 e-10$ & $-1.14 \mathrm{e}-08^{\star \star \star}$ & $-2.34 \mathrm{e}-10^{\star \star *}$ \\
\hline & $(1.02 \mathrm{e}-05)$ & $(1.78 \mathrm{e}-07)$ & $(7.47 \mathrm{e}-10)$ & $(7.27 \mathrm{e}-11)$ \\
\hline \multirow[t]{2}{*}{ Size of firm (L.Size) } & $0.200^{\star \star \star}$ & $0.00350^{\star \star *}$ & $0.144^{\star \star \star}$ & $0.00296^{* * *}$ \\
\hline & $(0.0254)$ & $(0.000816)$ & $(0.0168)$ & $(0.000912)$ \\
\hline \multirow[t]{2}{*}{ Index of corporate bonds issued in emerging markets (L.CEMBI) } & $-0.0137^{\star \star \star}$ & $-0.000240^{\star *}$ & $-0.00958^{\star * *}$ & $-0.000197^{\star *}$ \\
\hline & $(0.00457)$ & $(9.34 \mathrm{e}-05)$ & $(0.00324)$ & $(8.56 \mathrm{e}-05)$ \\
\hline \multirow[t]{2}{*}{ Size of derivatives market (L.Deriv) } & $2.92 \mathrm{e}-05^{\star \star \star}$ & $5.10 \mathrm{e}-07^{\star \star}$ & $2.75 \mathrm{e}-05^{\star \star \star}$ & $5.66 \mathrm{e}-07^{\star * *}$ \\
\hline & $(1.09 e-05)$ & $(2.22 \mathrm{e}-07)$ & $(7.06 \mathrm{e}-06)$ & $(2.09 \mathrm{e}-07)$ \\
\hline \multirow[t]{2}{*}{ Variation of exchange rate against the dollar (L.VarTC) } & $-0.0117^{\star \star}$ & $-0.000204^{*}$ & $-0.00763^{\star *}$ & $-0.000157^{*}$ \\
\hline & $(0.00590)$ & $(0.000109)$ & $(0.00383)$ & $(9.53 e-05)$ \\
\hline \multirow[t]{2}{*}{ Materials } & $0.761^{\star \star \star}$ & $0.0133^{\star \star \star}$ & $0.659^{\star \star \star}$ & $0.0136^{\star \star \star}$ \\
\hline & $(0.248)$ & $(0.00512)$ & $(0.182)$ & $(0.00515)$ \\
\hline \multirow[t]{2}{*}{ Communications } & $0.685^{\star \star}$ & $0.0120^{* *}$ & $0.623^{\star \star \star}$ & $0.0128^{* *}$ \\
\hline & $(0.287)$ & $(0.00561)$ & $(0.208)$ & $(0.00569)$ \\
\hline \multirow[t]{2}{*}{ Energy } & $1.342^{\star \star \star}$ & $0.0234^{\star \star \star}$ & $1.252^{\star \star \star}$ & $0.0258^{\star \star \star}$ \\
\hline & $(0.334)$ & $(0.00746)$ & $(0.269)$ & $(0.00941)$ \\
\hline \multirow[t]{2}{*}{ Dummy variable for 2008 (D2008) } & $-1.151^{\star \star \star}$ & $-0.0201^{\star \star \star}$ & $-0.831^{\star \star \star}$ & $-0.0171^{\star \star \star}$ \\
\hline & $(0.253)$ & $(0.00575)$ & $(0.174)$ & $(0.00620)$ \\
\hline \multirow[t]{2}{*}{ Dummy variable for 2012 (D2012) } & $0.365^{\star \star}$ & $0.00637^{\star \star}$ & $0.186^{*}$ & 0.00383 \\
\hline & $(0.155)$ & $(0.00294)$ & $(0.0975)$ & $(0.00237)$ \\
\hline \multirow[t]{2}{*}{ Dummy variable for 2013 (D2013) } & $0.511^{\star \star \star}$ & $0.00892^{* \star \star}$ & $0.301^{\star * \star}$ & $0.00619^{\star \star}$ \\
\hline & $(0.164)$ & $(0.00330)$ & $(0.103)$ & $(0.00280)$ \\
\hline \multirow[t]{2}{*}{ Dummy variable for 2014 (D2014) } & $0.461^{* \star \star}$ & $0.00805^{\star *}$ & $0.239^{\star \star}$ & $0.00493^{*}$ \\
\hline & $(0.161)$ & $(0.00314)$ & $(0.105)$ & $(0.00265)$ \\
\hline \multirow[t]{2}{*}{ Constant } & $-4.833^{\star * \star}$ & & $-3.707^{\star \star \star}$ & \\
\hline & $(0.614)$ & & $(0.393)$ & \\
\hline Observations & 8.817 & 8.817 & 8.817 & 8.817 \\
\hline ID number & 1.514 & & & \\
\hline Wald p-value & $<0$ & & $<0$ & \\
\hline Akaike information criterion (AIC) & 1965 & & 2297 & \\
\hline Bayesian information criterion (BIC) & 2163 & & 2489 & \\
\hline Pseudo R2 & & & 0.221 & \\
\hline Percentage correctly predicted (PCP) & & & 96.22 & \\
\hline
\end{tabular}

Source: Prepared by the authors.

Note: The standard error is shown in brackets: ${ }^{* \star} p<0.01,{ }^{* \star} p<0.05$ and ${ }^{*} p<0.1$.

ID: unique gateway identification (Bloomberg ticker). 
The coefficient for the corporate governance indicator is not only high but also has a positive sign, which suggests that the probability of a bond issue being carried out successfully increases as a firm complies with higher and higher standards of corporate governance. In addition, the coefficient for leverage is also high and has a positive sign, indicating that companies that have issued bonds before are likely to be able to draw on that experience to heighten their chances of successfully conducting subsequent corporate debt issues on the international market. Interestingly, the estimated term for the square of the leverage ratio is also highly significant at conventional levels. However, although its numerical magnitude is similar to that of the leverage coefficient, the sign of its square is negative in both models, which suggests that there may be an optimum level of indebtedness after which it has decreasing effects on the possibility of successfully issuing fresh debt. The coefficient for company size is also very high and positive, which supports the hypothesis that firm size may be a contributing factor in successful bond issues on international markets.

The estimates indicate that operations in the energy, materials and communications sectors, in that order, had a highly significant positive impact on the probability of conducting a successful international bond issue. The dummy variable for 2008 was highly significant and carried a negative sign, whereas the coefficients for the years 2012, 2013 and 2014 were significant and positive.

\section{Conclusions}

Since 2009, the corporate bond market has been steadily becoming a more and more important source of financing for Latin American firms. Its growing role can be attributed in part to the buoyancy of the world economy triggered by the low interest rates established by government authorities in response to the 2008 financial crisis and to the policy of quantitative easing applied by the United States Federal Reserve, which had a powerful influence on international bond yields. This also constitutes a risk, however, since any change in these favourable global conditions (particularly the stance adopted by the United States monetary authority) could cause this source of financing for Latin American firms to dry up, which could threaten the stability of the region's economies.

This paper presents the results of a study in which the debt issues indicator developed by ECLAC, CAF and IDB was used to analyse the importance of compliance with corporate governance principles and good practices in Brazil and the four Latin American countries that have joined together in the Latin American Integrated Market (MILA). An econometric analysis based on a panel data probit model and a pooled probit model shows that firms that comply more fully with corporate governance principles and standards of best practice may have a much greater probability of conducting a successful international bond issue. The findings reported on in this paper underscore the importance of the role that good corporate governance, which involves the efficient and timely disclosure of relevant information, may play in ensuring transparency. Of course, these results may also be interpreted as signifying that the proper regulation of corporate activity in ways that minimize conflicts of interest and information asymmetries can help companies gain greater access to international bond markets as a source of the financing they need to pursue their production activities. 


\section{Bibliography}

Bhagat, S. and B. Bolton (2008), "Corporate governance and firm performance", Journal of Corporate Finance, vol. 14, No. 3, Amsterdam, Elsevier.

BIS (Bank for International Settlements) (2016a), "Debt securities statistics" [online] https://www.bis.org/ statistics/secstats.htm?m=6\%7C33\%7C615.

(2016b), "OTS derivatives statistics at end-December 2015", May [online] https://www.bis.org/publ/ otc_hy $1605 . h t m$.

_ (2015), "Triennial Central Bank Survey of Foreign Exchange and Derivatives Market Activity in 2013" [online] http://www.bis.org/publ/rpfx13.htm.

BIS/ECB/IMF (Bank for International Settlements/European Central Bank/International Monetary Fund) (2015), Handbook on Securities Statistics, Washington, D.C., International Monetary Fund (IMF).

CAF (Andean Development Corporation) (2013), Lineamientos para un código latinoamericano de gobierno corporativo [online] http://publicaciones.caf.com/media/25389/lineamientos_codigo_latinoamericano.pdf.

CBOE (Chicago Board Options Exchange) [online] https://www.cboe.com/micro/vix/vixwhite.pdf.

Çelik, S., G. Demirtas and M. Isaksson (2015), "Corporate bonds, bondholders and corporate governance", OECD Corporate Governance Working Papers, No. 16, Paris, OECD Publishing.

Financial Times (2016), 14 July.

FRC (Financial Reporting Council) (2011), Guidance on Board Effectiveness, London, March. (2008), Combined Code of Corporate Governance, London, June.

Gozzi, J. C. and others (2015), "How firms use corporate bond markets under financial globalization", Journal of Banking \& Finance, vol. 58, Amsterdam, Elsevier.

G20/OECD (Group of 20/Organization for Economic Cooperation and Development) (2015), G20/OECD Principles of Corporate Governance. OECD Report to G20 Finance Ministers and Central Bank Governors [online] https://www.oecd.org/daf/ca/Corporate-Governance-Principles-ENG.pdf.

IMF (International Monetary Fund) (2015), "Coordinated Portfolio Investment Survey (CPIS)" [online] http:// data.imf.org/?sk=B981B4E3-4E58-467E-9B90-9DE0C3367363.

J. P. Morgan (2016), Fixed Income Index Product Guide, London, January.

Margaritis, D. and M. Psillaki (2010), "Capital structure, equity ownership and firm performance", Journal of Banking \& Finance, vol. 34, No. 3, Amsterdam, Elsevier.

MILA (Latin American Integrated Market) [online] mercadomila.com/.

Mizen, P. and S. Tsoukas (2012), "The response of the external finance premium in Asian corporate bond markets to financial characteristics, financial constraints and two financial crises", Journal of Banking \& Finance, vol. 36, No. 11, Amsterdam, Elsevier.

Núñez, G. and A. Oneto (coords.) (2015), "Corporate governance in Brazil, Chile, Colombia, Mexico and Peru: the determinants of risk in corporate debt issuance", Project Documents, No. 654 (LC/W.654), Santiago, Economic Commission for Latin America and the Caribbean (ECLAC) [online] https://repositorio.cepal. org/handle/11362/37721.

(2014), "La gobernanza corporativa y la emisión de deuda corporativa en Chile y el Perú: el papel de los inversionistas institucionales, las agencias calificadoras de riesgo y la banca de inversión", Project Documents, No. 624 (LCM.624), Santiago, Economic Commission for Latin America and the Caribbean (ECLAC) [online] https://repositorio.cepal.org/handle/11362/37387.

_ (coords.) (2012), "Gobernanza corporativa en el Brazil, Colombia y Mexico: la determinación del riesgo en la emisión de instrumentos de deuda corporativa", Project Documents (LC/W.468), Santiago, Economic Commission for Latin America and the Caribbean (ECLAC).

OECD (Organization for Economic Cooperation and Development) (2015), G20/OECD Principles of Corporate Governance, Paris, OECD Publishing.

Pérez Caldentey, E. (2017), "Quantitative easing (QE), changes in global liquidity and financial instability", Working Paper, No. 1701, Post Keynesian Economics Study Group [online] www.postkeynesian.net/ downloads/working-papers/PKWP1701_Oo3Adk2.pdf.

Rodrigues Bastos, F., H. Kamil and B. Sutton (2015), "Corporate financing trends and balance sheet risks in Latin America", IMF Working Papers, No. 15/10, Washington, D.C., International Monetary Fund (IMF).

Rogoff, K. (2015), "Was quantitative easing the best way to boost the U.S. economy?", The Boston Globe, 1 March [online] https://www.bostonglobe.com/business/2015/03/01/was-best-way-boosteconomy/2A3u8T6IWLzPpPRmssRd4K/story.html.

Tromben, C. and others (2015), "Se busca director", América Economía, No. 107, May-June.

WFE (World Federation of Exchanges) [online] https://www.world-exchanges.org/home/index.php/statistics. 